\title{
Sofia 2005
}

\author{
By Ron Holloway \\ Spring 2006 Issue of KINEMA
}

\section{SOFIA INTERNATIONAL FILM FESTIVAL 2005}

Film festivals in Central and Eastern Europe - "CentEast" in EU parlance - don't get much better than the $10^{\text {th }}$ Sofia International Film Festival (9-19 March 2006) under its charismatic director Stefan "Kita" Kitanov. One glance at the 160-page SIFF catalogue tells most of the story - prominently displayed are circa 80 sponsors and partners. Moreover, these sponsors are said to contribute the lion's share of this year's 250,000 Euro budget, in contrast to reported city and government funding at a meagre 25,000 Euros. Altogether, 160 films (100 features, 30 documentaries, 30 shorts) from circa 40 countries were booked for viewing by an estimated audience of 70,000, that figure apparently including attendance at follow-up events in Plovdiv and Burgas that stretch the SIFF out for another full week. According to an SIFF bulletin, this year's 250 applications for entry in the competition doubled the number received in 2005. And in a press release Kitanov was particularly enthusiastic about 2006 being an extraordinary year for Bulgarian cinema: "At the festival we are presenting 10 new feature films to visiting festival directors and selection committee members." In other words, the $10^{\text {th }}$ SIFF should confirm the promise of a "New Bulgarian Cinema." To back this prediction up, he cited the Bulgarian winners in the Regional Competition at the Sarajevo Film Festival: Zornitsa Sophia's Mila ot Mars (Mila from Mars) in 2004 and Georgi Djulgerov's Leidi Zi (Lady Zee) in 2005.

SIFF 2006 opened with Jean-Pierre and Luc Dardenne's L'Enfant (The Child, Belgium-France), Golden Palm winner at Cannes, and closed with Fatih Akin's Crossing the Bridge: The Sound of Istanbul (Germany), another Cannes highlight. British director Sir Alan Parker, honoured with one of the festival's five Life Achievement Awards, spiced his retrospective tribute with an exhibition of his humorous cartoons on the foibles of film producers. Other Life Achievement Awards were handed to German director Volker Schlöndorff, British actress Vanessa Redgrave, and Bulgarian directors Rangel Vulchanov and Nikolai Volev. Besides the International Competition (open to first and second features), crowds cued for many entries in the sidebar sections:

Galas \& Avant-Premieres, European Screen, Balkan Films Showcase, Bulgarian Features, Bulgarian Shorts, Sir Alan Parker Retrospective (British Film Council), Directors in Spotlight (Dardenne Brothers, Monty Python, Radivoje Andri, Kim Ki-Duk), World Screen, German Films (Goethe-Institut Sofia), Documentary Program, Nikolai Volev Retrospective, Zlatina Russeva Retrospective, and Special Screenings.

The International Jury, headed by Russian critic Andrei Plakhov, awarded the Stella Artois Grand Prix to Alexei Gherman Jr.'s Garpastum (Latin for Ball Game, Russia), a prize well deserved despite the coincidence of national origin. Set in St. Petersburg in the summer of 1914, just before the outbreak of World War One, this coming-of-age film chronicles the fumbling efforts of four young soccer enthusiasts to form a neighbourhood team, one of whom is distracted in his endeavours by a love affair with an older woman. Although none of the protagonists are as yet aware that their dreams will be shattered by the coming war and the 1917 Revolution, those events do hang ominously over the story like an approaching summer storm. "This is also the story of my generation," said Alexei Gherman Jr. in the Garpastum press book. "Our lives were very similar to the generation that lived at the beginning of the century." A Special Mention was given by the jury to Nenad Juric's debut feature Nebo iznad krajolika (Skies Above the Landscape, Bosnia and Herzegovina), a light comedy about a French miss stranded in the Bosnian mountains where her hip lingo is equated with merry misunderstanding. Unfortunately, the International Jury overlooked Tudor Giurgiu's Legaturi bolnavicioase (Love Sick, Romania), an eye-catching tale of a fragile relationship between two young precocious students (Iona Barbu and Maria Popistasu), one of whom is still wrestling with the demons of an incestuous affair with her brother.

Watched just as closely by visiting critics were the non-statuary citations awarded to Balkan and Bulgarian entries. The Kodak Award for Best Bulgarian Film went to Georgi Djulgerov's Leidi Zi (Lady Zee), the same 
winner of the top award in the Regional Competition at the 2005 Sarajevo film festival. The story of an orphan girl who makes her way into the outside world as a crack shot in shooting contests, Lady Zee also was awarded the FIPRESCI (International Critics) Prize at Sofia. The No Man's Land Award for Best Balkan Film went to Jan Cvitkovi's Odgrobadogroba (Gravehopping, Slovenia-Croatia), which also received the top award last November at the Cottbus Festival of Central and Eastern European Cinema. And the brand new Nisi Masa Award by a jury of young European film professionals was given to Isa Qosja's Kukumi (The Kukum, Kosovo-Croatia), shot in Kosovo and one of the strong entries last year in the Regional Competition at the Sarajevo film festival. Add to these winners two more awards of even greater international importance - the Un Certain Regard Prize given last year at Cannes to Cristi Puiu's Moartea domnului Lazarescu (The Death of Mister Lazarescu, Romania) and the Golden Bear given this year at the Berlinale to Jasmila Zbani's Grbavica (Bosnia) - and Balkan cinema is now a major attraction on the international festival circuit.

As for the lineup of New Bulgarian Productions, one was a standout although still in postproduction: Milena Andonova's Maimyni prez zumaka (Monkeys in Winter), an interwoven tale about the fate of three pregnant women in three different time periods (1960s, 1980s, the present), a film that also accurately mirrors the country's social and political conditions during those times. It should be added that Milena Andonova is the daughter of the late Metodi Andonov, whose Kozijat rog (The Goat Horn, 1972) ranks as the greatest box office hit in the history of Bulgarian cinema. Another promising Bulgarian feature film production, shown only as a work-in-progress, was Iglika Trifonova's Razledvane (Investigation), a Cain-and-Abel crime drama in which a woman investigator must determine who is more guilty than others in a murder of a man by his own brother. On the documentary side were some quite amusing tongue-in-cheek commentaries on life and times in Bulgaria. In Edna stydena Coca-Cola prez stydenata voina (A Cold Coke in the Cold War) co-directed by the trio of Damyan Petrov, Irina Nedeva, and Evgenia Atanasova - the story of how Coca-Cola pierced the Iron Curtain to make its way into Bulgaria in 1965 is told with a straight face by a secret-service man assigned to bring back a "lemonade" from a company based in Paris. No, it's not a mockumentary. According to the eyewitness account by the man on this secret mission, he just didn't know that "Fanta" happened to be another brand-name under the Coca-Cola label. And that's only part of this hilarious tale of messed-up diplomacy! Another delightful comedy of errors documentary was Svetoslav Draganov's Samodeytzi (Amateurs), a feature-length chronicle of events surrounding an "Amateur Theatre Festival" in the provincial town of Topolovgrad in the south of Bulgaria near the Greek border. By filming at intervals over the stretch of a couple years, Draganov was able to win the confidence of these stage enthusiasts while at the same time digging behind the scenes to take the pulse of democracy during a local election. Amateurs and A Cold Coke in the Cold War could easily supply those welcomed comic interludes at any key documentary film festival.

Topping it all off at SIFF 2006 was a rousing performance by the Festival Band in the Boyana Studios. Sometimes known as "The Three Stefan's," the core of the Festival Band consists of guitar-players Stefan Kitanov (Sofia), Stefan Laudyn (Warsaw), and Stefan Uhrik (Independents Section, Karlovy Vary). Thus far, they have toured with eye-popping success at festivals in Sarajevo, Utrecht, Berlin, Karlovy Vary, and Sofia. Asked whether a documentary about the band might be in the works, Stefan Kitanov usually replies with a noncommittal "maybe" or "we'll see." All the same, everyone present at the Boyana Studio performance felt that this performance by the growing six-piece band was the best until now. And why not? Stefan Kitanov launched SIFF ten years ago on the foundation of a successful rock festival. And it's been growing in prestige ever since. As one observer noted, what better introduction to membership in the European Union.

\section{Nisi Masa}

Want to know what made SIFF particularly memorable this year? For my taste, as an old-style journalist who feeds unashamedly off the energy of young filmmakers, it was the presence of Nisi Masa, before and during the festival, that made this trip the best cinema event I have yet experienced of the 21st century.

"Nisi Masa" - its title referring (I guess) to something scrawled on a wall in Fellini's 8 1/2 - was founded in Paris in 2001 by a group of young cineastes (originally from France, Italy, Belgium, Spain and Finland) with the support of the EU's "Youth \& Media Programme" and has become an ever-evolving European Network of Young Cinema. Its aims are four-fold: (1) to discover new film talent, (2) to foster European awareness through cinema, (3) to develop cross-cultural cinema projects, and (4) to create a platform of discussion and collaboration for young European filmmakers. 
I got interested last year when I heard that Nisi Masa had successfully organized in Turkey a seminar on Human Rights. Not an easy mandate, considering. So, this year, when I was invited by Elena Masholova of Nisi Masa Sofia to help moderate a week-long seminar in the university city of Blagoevgrad in the south of Bulgaria on "Balkan Cinemas, Balkan Identities," I jumped at the chance. Particularly since most of the 30 participants, film talent between the ages of 20 and 30, came from across the Balkans - Bulgaria, Romania, Transylvania, Croatia, Serbia, Vojvodina, Kosovo, Macedonia, you name it - and because an international jury of young filmmakers were to award a Nisi Masa Prize at the Sofia film festival.

The prize went to Isa Qosja's Kukumi (Kosovo), a poetic, surrealistic tale about a trio of inmates released from an insane asylum at the close of the war in Kosovo in 1999. The landscape, a barren stretch of desert reflecting the disorientation of the Kosovo populace, plays as much a role in the film as "the Kukum," one of the inmates on the loose who is eventually shot by mistake by a NATO tank commander.

But if I were to give a prize to a film seen at the Nisi Masa seminar in Blagoevgrad, it would go to Srdjan Keca's After the War (Serbia), a 47-minute documentary produced at Atelier Varan Belgrade. Shot in southern Kosovo, the documentary took months to complete and only after repeated visits to win the confidence of mountain villagers. In this isolated corner of the Balkans live an Islamic minority of Slavic origin, the Gorani, a people without a country of their own. What had kept them together and protected them for centuries was their homeland, the Gora mountains of southern Kosovo, located today along the borders to Serbia, Macedonia, and Albania. As it happened, the Gorani, although Muslim in religion, suffered the misfortune of fighting mostly on the side of the Serbs. Today, surrounded by the Albanian majority, the Gorani are faced with the alternative of emigration or re-integration. Provided those dark memories of the Kosovo War can be forgotten.

If that's what Nisi Masa seminars are all about, then invite me again.

\section{References}

\section{AWARDS}

International Competition

Stella Artois Grand Prix

Garpastum (Latin for Ball Game, Russia)

dir Alexei German Jr.

\section{Special Mention}

Nebo iznad krajolika (Skies Above the Landscape), Bosnia and Herzegovina) dir Nenad Juri

Other Awards

Kodak Award - Best Bulgarian Feature Film

Leidi Zi (Lady Zee), dir Georgi Djulgerov

Jameson Short Film Award - Best Bulgarian Short Film

Cherno na bylo (Black on White)

dir Andrei Tzvetkov

Special Mention

Kaloyan \& Sonya

dir Boginya Naidenova

Audience Award

The White Countess (UK-USA-Germany-China)

dir James Ivory

No Man's Land Award - Best Balkan Film

Odgrobadogroba (Gravehopping, Slovenia-Croatia)

dir Jan Cvitkovi 
FIPRESCI (International Critics) Award Leidi Zi (Lady Zee, (Bulgaria)

dir Georgi Djulgerov

"Nisi Masa" Jury Award

Kukumi (The Kukum, Kosovo-Croatia)

dir Isa Qosja

Best Pitching Award - Sofia Meetings

Teah (Slovenia), Hanna A.W. Slak (director), Dunja Klemenc (producer)

Bulgarian "Bitter Cup" Awards

(Journalism \& Mass Communication Dept, St. Kliment Okhridski University)

Nikolai Volev, writer-director

Ivan Tonev, director-coscript, Tanya Shahova, script, Lybovta e... (Love Is...)

Life Achievement Awards

Alan Parker (UK), director

Nikolai Volev (Bulgaria), director

Rangel Vulchanov (Bulgaria), director

Volker Schlöndorff (Germany), director

Vanessa Redgrave (UK), actress

\section{Author Information}

Ron HOLLOWAY (1933-2009) was an American critic, film historian, filmmaker and correspondent who adopted Europe as his home in the early fifties and spent much of his life in Berlin. He was an expert on the study of German cinema and against all odds produced, with his wife Dorothea, the journal German Film, keeping us up-to-date with the work of directors, producers and writers and the showing of German films around the world.

In 2007, Ron Holloway and his wife were awarded the Berlinale Camera Award. Ron also received the Bundesverdienstkreuz (German Cross of Merit), Polish Rings, Cannes Gold Medaille, the American Cinema Foundation Award, the Diploma for Support of Russian Cinema and an honorary award from the German Film Critics' Association.

Ron was also a valued contributor to Kinema for the past fifteen years. 